\title{
Analysis of Environmental Contaminants in Australian Honey and Comparison to Stingless Bee Honey from Queensland and Malaysia ${ }^{\dagger}$
}

\author{
Natasha L. Hungerford 1,*, Benjamin L. L. Tan ${ }^{2}$, Ujang Tinggi ${ }^{2}$, Norhasnida Zawawi ${ }^{1,4}$, \\ Madeleine Farrell ${ }^{2}$, Heng Hang Tsai ${ }^{2}$, Darina Hnatko ${ }^{2}$, Lorinda J. Swann ${ }^{2}$, Cassandra L. Kelly ${ }^{2}$, \\ Shalona R. Anuj ${ }^{2}$, Dennis C. Webber ${ }^{3}$, Stephen T. Were ${ }^{3}$ and Mary T. Fletcher ${ }^{1}$ \\ 1 Queensland Alliance for Agriculture and Food Innovation (QAAFI), The University of Queensland, \\ Health and Food Sciences Precinct, Coopers Plains, Qld 4108, Australia; n.zawawi@uq.edu.au (N.Z.); \\ mary.fletcher@uq.edu.au (M.T.F.) \\ 2 Forensic and Scientific Services, Queensland Health, Coopers Plains, Qld 4108, Australia; \\ Benjamin.Tan@health.qld.gov.au (B.L.L.T.); Ujang.Tinggi@health.qld.gov.au (U.T.); \\ Madeleine.Farrell2@health.qld.gov.au (M.F.); HengHang.Tsai@health.qld.gov.au (H.H.T.); \\ Darina.Hnatko@health.qld.gov.au (D.H.); Lorinda.Swann@health.qld.gov.au (L.J.S.); \\ Cassandra.Kelly@health.qld.gov.au (C.L.K.); Shalona.Anuj@health.qld.gov.au (S.R.A.) \\ 3 Queensland Department of Agriculture and Fisheries, Health and Food Sciences Precinct, Coopers Plains, \\ Qld 4108, Australia; Dennis.Webber@daf.qld.gov.au (D.C.W.); Stephen.Were@daf.qld.gov.au (S.T.W.) \\ 4 Faculty of Food Science and Technology, Universiti Putra Malaysia, UPM Serdang 43400, Selangor, \\ Malaysia; norhasnida@upm.edu.my \\ * Correspondence: n.hungerford@uq.edu.au \\ + Presented at the third International Tropical Agriculture Conference (TROPAG 2019), Brisbane, Australia, \\ 11-13 November 2019.
}

Published: 13 February 2020

\begin{abstract}
Honey is a widely available natural sweetener containing sugars, and small quantities of vitamins and minerals, proteins, amino acids and fatty acids. Owing to its nutritious components, commercial honeys are sold in bulk blends or as trendy and premium products. Meanwhile, honey bees are considered as environmental monitors and have the potential to transfer environmental contaminants, if present, to honey. In high density urban and industrial environments polycyclic aromatic hydrocarbons (PAHs) and heavy metals can be prevalent, whilst pesticides and mineral and trace elements are ubiquitous. Honey hives are traditionally located in rural and forested areas, but there is a growing trend to locate hives in urban areas. This project has investigated the presence of environmental contaminants in honey samples from high density urban, peri-urban as well as rural areas. Australian honey samples $(n=211)$ were purchased between 2016 and 2018, including 52 honeys claiming to be of urban origin purchased online. Stingless bee honeys $(n=36)$ from Queensland and Malaysia were compared. Processed samples were analysed by UHPLC-MS/MS (herbicides), GC-MS/MS (pesticides and PAHs) and ICP-MS and ICP-OES (elemental analyses). The results showed low or negligible pesticide, herbicide, and PAH contamination, and that these low results were similar regardless of urban or rural origins. Wide variations of essential trace element $(\mathrm{Fe}, \mathrm{Zn}, \mathrm{Cu}, \mathrm{Mo}, \mathrm{Co}, \mathrm{Mn}, \mathrm{Cr}$ ) and mineral levels $(\mathrm{K}, \mathrm{Na}, \mathrm{P}, \mathrm{Mg}, \mathrm{Ca})$ were found in honey products, which are a good dietary source of $\mathrm{K}$ and $\mathrm{Zn}$. Relatively low levels of toxic heavy metals were found in honeys.
\end{abstract}

Keywords: honey; environmental contaminants; Queensland; Malaysia; stingless bee honey 
Author Contributions: Concept, N.L.H., N.Z. M.T.F.; extraction, methodology, validation, B.L.L.T., D.H., L.J.S., H.H.T. S.A., M.F.; data analysis, B.L.L.T, U.T., N.L.H.; investigation, advice N.L.H., D.C.W., S.T.W; writing, N.L.H., M.T.F.; supervision, M.T.F.; funding acquisition, B.L.L.T, U.T., N.L.H., N.Z., M.T.F.

Funding: This work was funded by Queensland Health Grant RSS18-002.

Acknowledgments: Dr Tim Heard sourced honeys for Queensland stingless bees. Stingless bee honeys were collected in Malaysia with funding from Transdisciplinary Research Grant Scheme (TRGS) by the Ministry of Education (MOE), Malaysia, reference code TRGS/1/2016/UPM/01/5/4 and Universiti Putra Malaysia supported travel to Australia for N.Z.

Conflicts of Interest: The authors declare no conflict of interest.

(C) 2020 by the authors. Licensee MDPI, Basel, Switzerland. This article is an open access article distributed under the terms and conditions of the Creative Commons Attribution (CC BY) license (http://creativecommons.org/licenses/by/4.0/). 